\title{
KARAKTERISTIK FISIK RUMAH ADAT GORONTALO (DULOHUPA DAN BANTAYO POBO'IDE)
}

\author{
Rahmawati Eka
}

\begin{abstract}
Abstrak
Tujuan penelitian menganalisis karakteristik fisik Rumah Adat Gorontalo. Metode penelitian paradigma rasionalistik dengan lokasi Kota Gorontalo dan Kabupaten Limboto. Survey lapangan dilakukan pada bulan November - Desember 2015, dimulai dengan pengambilan data awal dilanjutkan dengan wawancara semiterstruktur, observasi lapangan kemudian strukturisasi data, serta konfirmasi data dengan kenyataan di lapangan dan pandangan tokoh adat. Hasil penelitian menunjukkan bahwa karakteristik fisik kedua rumah adat sebagai berikut: (1) luasan, Dulohupa lebih kecil daripada Bantayo Pobo'ide. (2) Organisasi ruang, Dulohupa memiliki susunan ruang lebih sederhana, jumlah ruang lebih sedikit (7 ruang), dan fungsi utamanya untuk kegiatan adat, sedangkan Bantayo Pobo'ide lebih rumit, ruang lebih banyak (22 ruang), dan fungsi utamanya untuk kegiatan adat dan kediaman raja. Karakteristik yang lebih mengacu pada falsafah adat gorontalo yaitu "adati hula-hula'a to sara'a, sara'a hula-hula'a to kuru'ani" karena menurut tinjauan historis Gorontalo raja pertama masuk Islam sehingga semua adat istiadat budayanya menganut ajaran Islam.
\end{abstract}

\section{Kata kunci: Karakteristik fisik, Dulohupa dan Bantayo Pobo'ide}

\begin{abstract}
The study aims to investigate the characteristics of Gorontalo traditional house and its philosophical significance. The study was conducted with rasionalistic paradigm in Gorontalo city and Limboto Regency. A field survey was performed from November to December 2015, starting with preliminary data collection, then partly-structured interview, and data restructuring as well as confirmation with the field condition and with the traditional leaders' view. The study indicates thet the physical characteristics of both houses are (1) the size: Dulohupa has a smaller size than Bantayo Pobo'ide, (2) room management: Dulohupa has simple room layout, the number of rooms are only seven, and their function are for cultural activities. Bantayo Pobo'ide, however is more complicated: it has 22 rooms and its primary functions are for cultural activities and for the king residence. The characteristic that refers more to the customary philosophy of Gorontalo is "adati hula-hula'a to sara'a, sara'a hula-hula'a to kuru'ani" because according to Gorontalo historical review the first king entered Islam so that all cultural customs adhered to the teachings Islam.
\end{abstract}

\section{Keywords: Physical Characteristics, Dulohupa and Bantayo Pobo'ide}

\section{PENDAHULUAN}

Budihardjo (1994:57) rumah adalah aktualisasi diri yang diejawantahkan dalam bentuk kreativitas dan pemberian makna bagi kehidupan penghuninya. Selain itu rumah adalah cerminan diri, yang disebut Pedro Arrupe sebagai "Status Conferring Function", kesuksesan seseorang tercermin dari rumah dan lingkungan tempat huniannya.

Rumah Adat adalah bangunan yang memiliki ciri khas khusus, digunakan untuk tempat hunian oleh suatu suku bangsa tertentu. Rumah adat merupakan salah satu representasi kebudayaan yang paling tinggi dalam sebuah komunitas suku/masyarakat. Keberadaan rumah adat di Indonesia sangat beragam dan mempunyai arti yang penting dalam perspektif sejarah, warisan, dan kemajuan masyarakat dalam sebuah peradaban.

Rumah adat merupakan bangunan rumah yang mencirikan atau khas bangunan suatu daerah. Di Indonesia rumah adat adalah salah satu yang melambangkan kebudayaan dan ciri khas masyarakat setempat. Indonesia dikenal sebagai Negara yang memiliki keragaman dan kekayaan budaya. Rumah adat merupakan salah satu ciri khas suatu daerah untuk melambangkan budayanya, agar dapat membedakan antara budaya daerah tersebut dengan budaya daerah yang lain.

Menurut Spiro (dalam Koentjaraningrat 2000: 212) mengatakan bahwa "dalam karya ilmiah ada cara pemakaian fungsi yakni pemakaian yang menerangkan fungsi itu sebagai hubungan guna antara sesuatu hal dengan sesuatu tujuan yang tertentu. Misalnya rumah adat berfungsi sebagai pelengkap suatu kebudayaan tertentu yang mengungkapkan nilai-nilai budaya serta aspek lain yang berhubungan dengan kebudayaan daerah adat tersebut.

Berdasarkan pengamatan awal dan wawancara banyak ditemukan rumah tradisional suku Gorontalo yang sudah punah diakibatkan oleh kelapukan yang ada tinggallah beberapa rumah yang masih dihuni oleh keturunannya, karena beberapa sebab antara lain kepedulian terhadap warisan peninggalan terdahulu dan keluarga yang diberikan tanggung jawab masih mampu untuk merehab kerusakan tanpa 
menghilangkan keaslian dari karakter rumah tersebut.

Pelestarian tradisi dan budaya nenek moyang hingga saat ini masih tetap dilakukan namun hanya sebatas upacara adat seperti penyelenggaraan pesta kelahiran, pernikahan, kematian, dan lain-lain, sementara pelestarian budaya non fisik pada bangunan hanya beberapa saja yang masih menggunakan tradisi adat Momayango. Hal ini bisa dilihat pada tampilan bangunan-bangunan yang ada di Gorontalo baik hunian (pribadi, massal) maupun perkantoran, sangat sulit mendapatkan adanya penerapan unsur dan nilai arsitektur tradisional maupun vernakular setempat padahal identitas dari suatu wilayah pertama kali akan terlihat dari wujud bangunan/arsitekturnya.

Dari penjabaran di atas mengindikasikan minimnya pengetahuan masyarakat Gorontalo tentang kebesaran budaya yang terkandung pada arsitektur rumah adatnya. Kurangnya keperdulian masyarakat untuk melestarikan benda cagar budaya daerah sebagai unsur budaya nasional dan mengupayakan daerah ini menarik bagi wisatawan yang ingin berkunjung ke Gorontalo.

Melalui penelitian ini, peneliti bertujuan untuk mengungkap karakteristik fisik pada bangunan Bantayo Poboide (kerajaan Limutu) dan Dulohupa (Kerajaan Hulontalo).

\section{ISI PENELITIAN}

Penelitian ini adalah penelitian arsitektur dengan fokus kajian pada karakteristik fisik bangunan rumah adat Gorontalo dengan beberapa indikator penelitian dari variabel penelitian.

Penelitian ini menggunakan metode paradigma rasionalistik, dengan wilayah populasi survey penelitian difokuskan pada Kabupaten dan kota Gorontalo. Penetapan wilayah populasi ini berdasarkan sejarah lahirnya Gorontalo bahwa kedua daerah merupakan wilayah inti kerajaan besar yang ada di Gorontalo.

\subsection{Pembahasan}

Penelitian ini dilaksanakan di wilayah Provinsi Gorontalo, dengan wilayah populasi penelitian difokuskan di Kota Gorontalo dan Kabupaten Gorontalo. Penetapan wilayah populasi ini berdasarkan sejarah lahirnya Gorontalo dimana kedua daerah ini dahulu merupakan wilayah-wilayah kerajaan inti yang ada di Gorontalo.

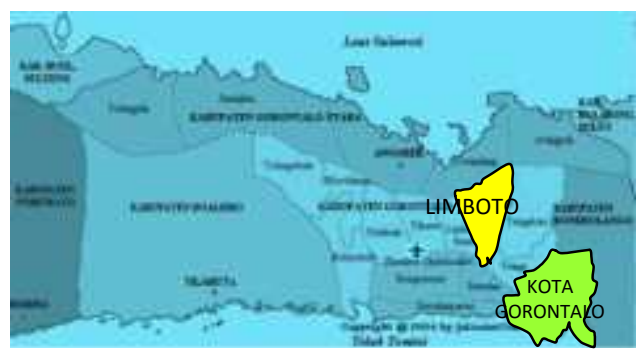

Gambar 1. Peta Provinsi Gorontalo
Diungkapkan Kimura, Profesor di Universitas Hawaii, Amerika Serikat, dengan menyimpulkan bahwa Provinsi Gorontalo berdiri bukan karena adanya kesenjangan atau ketegangan antara pusat dan daerah, melainkan justru untuk memperlebar akses dan hubungan baru dengan pusat yang selama ini terhambat ketika masih menjadi bagian dari Sulawesi Utara.

Gorontalo mengalami banyak perubahan sejak tahun 2000, menjelang daerah ini berdiri sebagai sebuah provinsi baru, 16 Februari 2001. Sejak itulah beragam harapan dan ujian baru terus mengemuka dan memperoleh ruang dalam perbincangan publik. Gorontalo adalah sebuah "proyek kultural" dan "konstrukteritorial" yang belum selesai. Dia masih akan terus dikerjakan, dibayangkan dan dirasakan dari waktu ke waktu oleh berubahnya cakrawala setiap generasi yang lahir dinegeri ini.

Tercatat dalam laporan kolonial bahwa tahun 1686 banjir besar melanda Gorontalo dan karena parah akibatnya maka VOC kemudian membatalkan tagihan upetinya kepada Gorontalo. Hutan Gorontalo sudah serius sejak lama, tak heran kalau tahun 1919 ditunjuk petugas khusus urusan kehutanan oleh pemerintah kolonial. Seorang pecinta hutan bernama Heringa (1921) melaporkan kondisi hutan Gorontalo pada tingkat yang sudah 'berbahaya' dan membutuhkan restorasi yang terukur.

\subsection{Latar Belakang Budaya Masyarakat Gorontalo}

Memasuki awal abad ke-20 penduduk wilayah Gorontalo mengalami peningkatan dengan rata-rata tingkat penduduknya sebesar $47,154 / \mathrm{km}^{2}$ dengan jumlah penduduk 565.848 jiwa. Peningkatan ini selain diakibatkan oleh faktor kelahiran penduduk, juga diakibatkan faktor perluasan administrasi pemerintah sehingga sejumlah tenaga didatangkan ke Gorontalo. Faktor migrasi juga menjadi penyebab peningkatan penduduk. (Apriyanto, 2012:17)

Meskipun satu suku bangsa, orang Gorontalo mengakui bahwa mereka terdiri atas sembilan sub kelompok etnik, yang masing-masing memiliki bahasanya sendiri. Atas dasar Geografis dan perbedaan bahasa serta dialek, maka kesembilan golongan itu diantaranya adalah : bahasa Atinggola Gorontalo sebelah Utara, bahasa Suwawa Gorontalo sebelah Timur, bahasa Jawa Tondano digunakan di Kaliyoso, Reksonegoro, Yosonegoro, bahasa Sangihe digunakan di kampung Karangetan, Paguat. Bahasa Tombulu digunakan dikampung Kaaruyan, Paguat. Bahasa Bajo digunakan dipesisir pantai Tilamuta dan Popayato. Bahasa Bolaang Mongondow, Jawa, Madura dan Sunda digunakan oleh Transmigran. Untuk bahasa Bugis dan Makassar yang digunakan oleh kelompok etnik untuk berkomunikasi antara sesamanya, sedangkan bahasa Arab dan Cina digunakan oleh orang arab dan cina (Apriyanto, 2012:7). 


\subsection{Latar Belakang Agama Masyarakat Gorontalo}

Dilihat dari konteks keagamaan, Islam merupakan agama yang paling banyak dianut oleh masyarakat Gorontalo. Adapun yang menjadi daya tarik islam adalah karena keunggulannya dalam konsep menyangkut nilai-nilai sosial yang lebih manusiawi dan demokratis serta rasional. Islam menempatkan individu pada penduduk dengan martabat yang sama. Kehadiran Islam telah memperbaiki kondisi sosial pada masa itu. Semasa pemerintahan Raja Eyato misalnya pada tahun 1673 1679 terjadi perubahan yang cukup besar dalam bidang hukum adat yang berlaku dikerajaan Gorontalo. Raja Eyato tidak memperkenankan adat yang bertentangan dengan syara' yang bersendikan Alquran. Prinsip adat yang mengacu pada ajaran Islam, oleh Van Vollenhoven meletakkan kebudayaan Gorontalo sebagai provinsi kebudayaan yang ke-9 dari 19 kelompok kebudayaan di Nusantara. (Apriyanto, 2012:10-11).

Kuno Kaluku pada seminar adat 1971 itu memberikan prasaran tentang 'sejarah adat istiadat dan agama Islam' yang secara terbuka memformulasikan ungkapan "adat bersendikan syara, syara bersendikan kitabullah", (Amin, 2012:30). Dalam disertasi Nur (1979), kita bisa mengenal Kuno Kaluku sebagai pensiunan kepala jawatan penerangan Gorontalo. Dia adalah salah satu pemrasaran utama dalam seminar 1971.

\subsection{Hasil penelitian Karakteristik Fisik Rumah Adat Gorontalo}

Tabel 1. Rumah Adat Dulohupa

\begin{tabular}{|c|c|c|c|}
\hline $\begin{array}{c}\text { Unit } \\
\text { Informasi }\end{array}$ & $\begin{array}{c}\text { Sub } \\
\text { Informasi }\end{array}$ & $\begin{array}{c}\text { Gambar Fisik } \\
\text { Rumah }\end{array}$ & Keterangan \\
\hline $\begin{array}{l}\text { 1.Organisas } \\
\text { i Ruang }\end{array}$ & $\begin{array}{l}\text { a. Palepelo } \\
\text { adati dan } \\
\text { Dulodehu } \\
\text { Material lantai: } \\
\text { konstruksi } \\
\text { papan kayu } \\
\text { Material plafon: } \\
\text { kayu (tebal } \\
\text { 3cm) } \\
\text { Warna cat: } \\
\text { coklat muda } \\
\text { b.Dulohupa } \\
\text { Material lantai: } \\
\text { konstruksi } \\
\text { papan kayu } \\
\text { (tebal 15cm) } \\
\text { Material } \\
\text { Dinding: papan } \\
\text { kayu (tebal } \\
\text { 10cm) } \\
\text { Material plafon: } \\
\text { kayu (tebal } \\
\text { 3cm) } \\
\text { Warna cat: } \\
\text { coklat tua } \\
\end{array}$ & 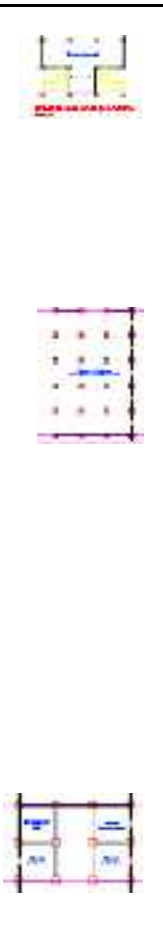 & $\begin{array}{l}\text { a. Palepelo adati dan } \\
\text { Dulodehu yaitu } \\
\text { tempat para pengawal } \\
\text { adat atau keamanan } \\
\text { ketika sedang } \\
\text { berlangsung } \\
\text { musyawarah dan } \\
\text { tempat berkumpul } \\
\text { para tamu } \\
\text { b. Dulohupa yaitu } \\
\text { ruang tengah dari } \\
\text { bangunan, khusus } \\
\text { untuk tempat } \\
\text { musyawarah hal yang } \\
\text { penting mengenai } \\
\text { daerah/kota } \\
\text { Gorontalo atau } \\
\text { sebagai pagelaran } \\
\text { upacara adat ketika } \\
\text { akan diselenggarakan } \\
\text { kegiatan } \\
\text { c. Huwali lo humbio } \\
\text { yaitu kamar adat } \\
\text { pengantin pria dan } \\
\text { wanita, fungsinya } \\
\text { untuk pembatalan air } \\
\text { wudhu dan tempat } \\
\text { bersandingnya kedua } \\
\text { mempelai di ranjang } \\
\text { adat. } \\
\text { Huwali lo wadaka } \\
\text { yaitu kamar rias } \\
\text { untuk mempelai } \\
\text { putri. } \\
\text { Huwali lo polungude } \\
\text { yaitu kamar khusus } \\
\text { pengantin putri ketika }\end{array}$ \\
\hline
\end{tabular}

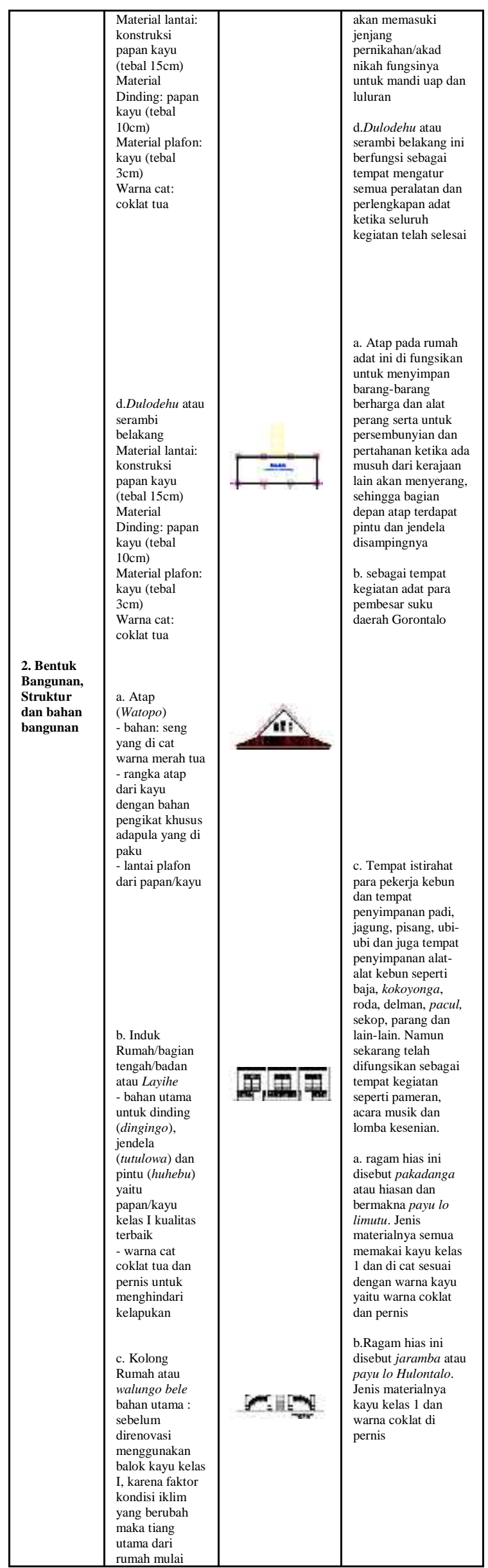




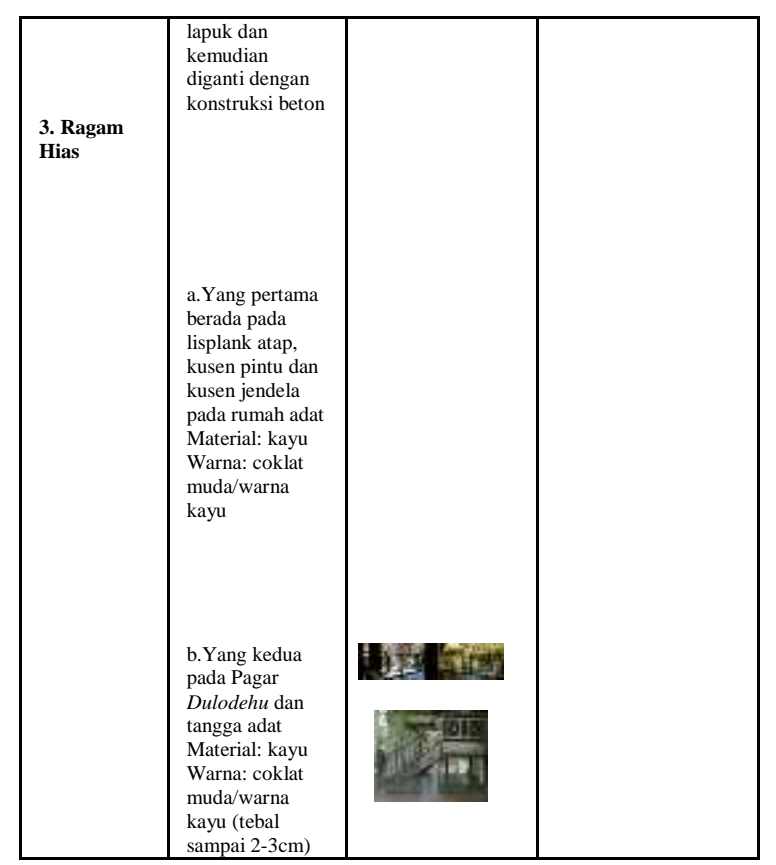

Tabel 2. Rumah Adat Bantayo Pobo'ide

\begin{tabular}{|c|c|c|c|}
\hline $\begin{array}{c}\text { Unit } \\
\text { Informasi }\end{array}$ & $\underset{\text { Informasi }}{\text { Sub }}$ & $\begin{array}{c}\text { Gambar } \\
\text { Rumah }\end{array}$ & Keterangan \\
\hline $\begin{array}{l}\text { 1.Organisas } \\
\text { i Ruang }\end{array}$ & $\begin{array}{l}\text { b. Dulodehu } \\
\text { Material lantai: } \\
\text { konstruksi } \\
\text { papan/kayu } \\
\text { (tebal sampai } \\
\text { 5cm) } \\
\text { Material } \\
\text { dinding: papan } \\
\text { kayu (tebal 2,5- } \\
\text { 3cm) } \\
\text { Material } \\
\text { plafon: } \\
\text { papan/kayu } \\
\text { (tebal 3cm) } \\
\text { Warna: coklat } \\
\text { tua } \\
\\
\\
\end{array}$ & 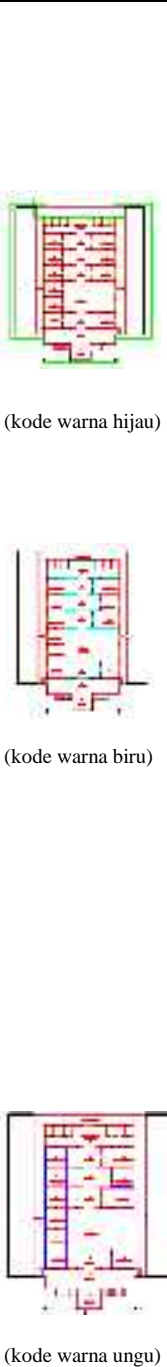 & 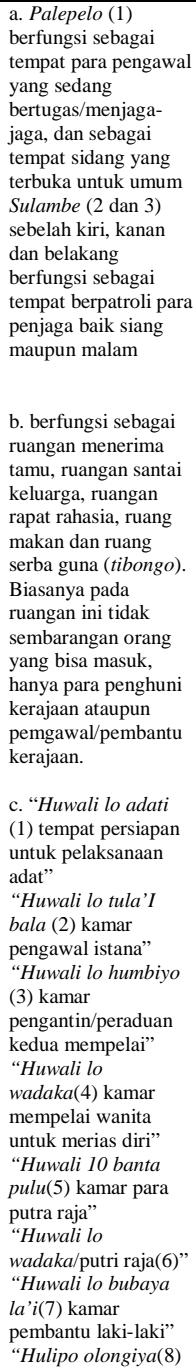 \\
\hline
\end{tabular}

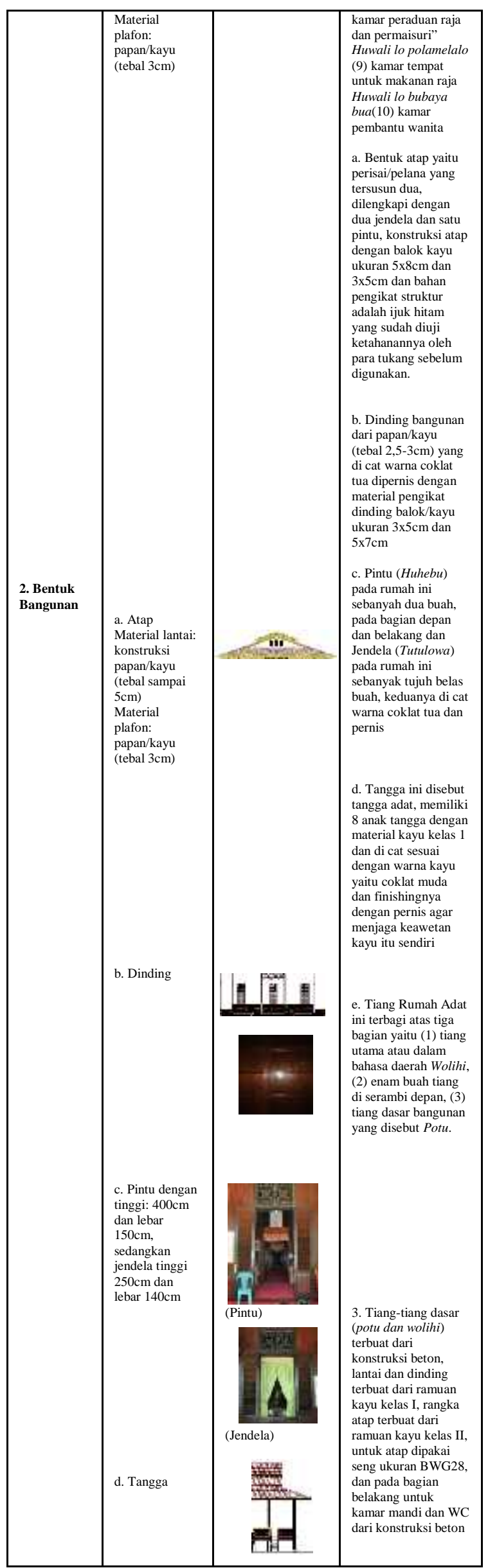




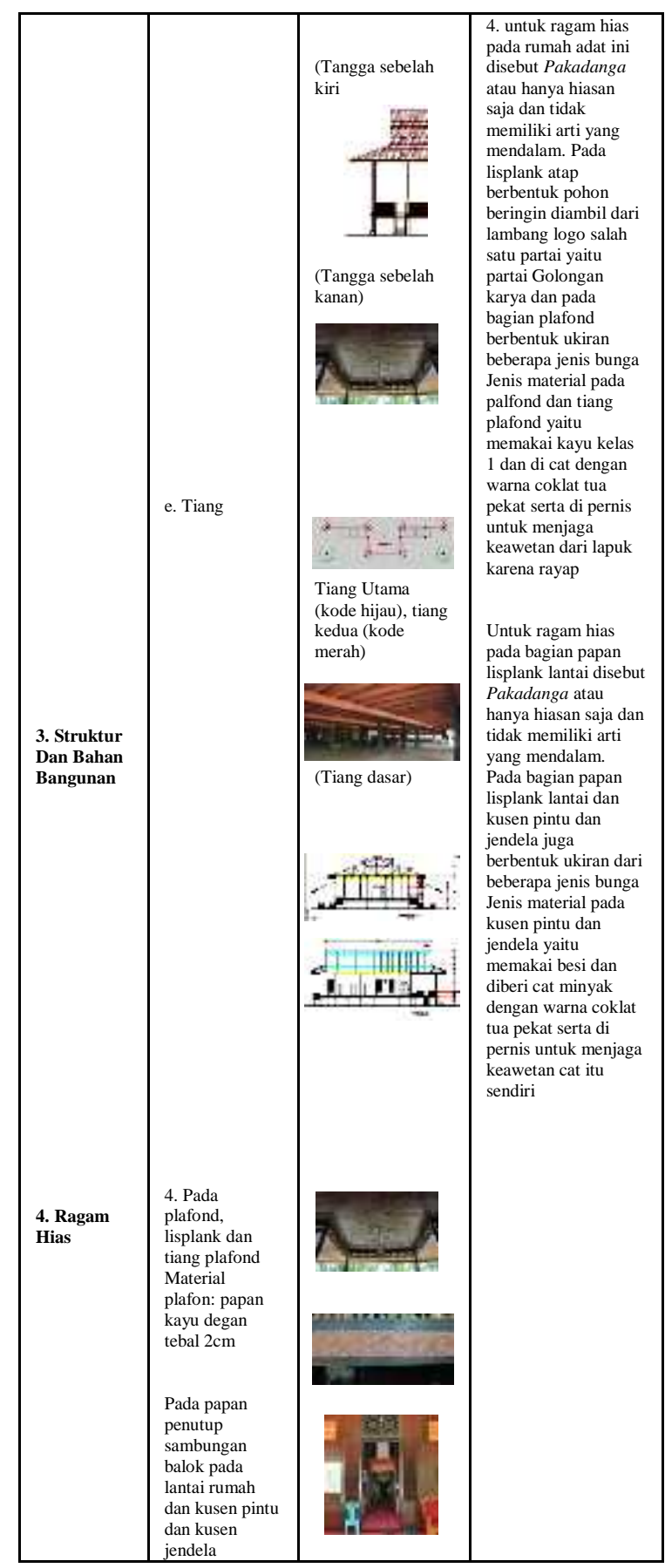

\section{KESIMPULAN}

Berdasarkan analisis terhadap dua sampel pada kedua wilayah lokasi kasus di Gorontalo yaitu sampel satu rumah adat Dulohupa berada di kota Gorontalo dan sampel dua rumah adat Bantayo Pobo'ide berada di Kabupaten Gorontalo atau Limboto. Pada hasil penelitian yang mengidentifikasi karakteristik fisik (tangible) rumah adat Dulohupa dan Bantayo Pobo'ide secara nyata dilapangan memiliki perbedaan pada fisik bangunan terutama pada luas bangunan dimana rumah adat Dulohupa memiliki luas lebih kecil dari pada rumah adat Bantayo Pobo'ide dan organisasi ruang khususnya jumlah ruang kamar pada kedua rumah adat tersebut. Pada rumah adat Dulohupa hanya memiliki empat organisasi ruang yaitu Palepelo adati dan Dulodehu, Dulodehu lo Dulohupa, Ruang Kamar (Huwali lo humbio, Huwali lo wadaka, Huwali lo Polungude dan WC) dan Dulodehu atau serambi belakang. Sedangkan Bantayo Pobo'ide memiliki tiga organisasi ruang yaitu Sulambe atau Palepelo, dulodehu dan huwali (Huwali lo adati, Huwali lo tula'I bala, Huwali lo humbiyo, Huwali lo wadaka, Huwali 10 banta pulu, Huwali lo wadaka/putri raja, Huwali lo bubaya la'I, Hulipo olongiya, Huwali lo polamelalo, Huwali lo bubaya bua).

Saran

Secara Teoritis :

a. Dapat dijadikan bahan referensi dalam rangka pengembangan ilmu arsitektur, khususnya dalan kajian teori rumah adat Kabupaten Gorontalo.

b. Dapat memberikan kontribusi bagi para peneliti selanjutnya untuk mengembangkan penelitian tentang rumah adat di Gorontalo.

c. Dapat dimanfaatkan sebagai bahan acuan bagi masyarakat khususnya para mahasiswa dalam rangka meningkatkan pengetahuan tentang rumah adatnya.

\section{DAFTAR PUSTAKA}

Apriyanto, Joni. 2012. Sejarah Gorontalo Modern Dari Hegemoni Kolonial Ke Provinsi. Yogyakarta: Penerbit Ombak

Budihardjo. (1994). Percikan Masalah Arsitektur,Perumahan Perkotaan, Penerbit Gajah Mada University, Press.

Daulima, Farha. Pateda, Karim (2001). Bantayo Poboide 'Struktur dan Fungsinya'.

Daulima, Farha dan Hapri, Harun. 2007. Mengenal Situs/Benda Cagar Budaya Di Provinsi Gorontalo. Gorontalo: Penerbit Forum Suara Perempuan LSM Mbu'I Bungale

Daulima, Farha. 2008. Dialog tentang Budaya Daerah bersama Bunda Farha. Gorontalo. Galeri Budaya Daerah LSM Mbu'i Bungale.

Nur. (1979). Beberapa Aspek Dan Hukum Adat Tata Negara Kerajaan Gorontalo Pada Masa Pemerintahan Eyato 1673-1679, (Ujung Pandang: UNHAS, 1979), h. 220

Wawancara langsung :

1. Bersama, Mantan Dewan Adat Kabupaten Gorontalo (H.Yamin Husain, SE)

2. Bersama, Bate Lo Hulondalo atau Juru Bicara Tokoh Adat Gorontalo (H. Dadi Kasim Usman)

3. Bersama, Dewan Adat Kota Gorontalo (Drs. H. Karim Pateda, MM)

4. Bersama, Sekretaris Dinas Kebudayaan dan Pariwisata Kota Gorontalo (H. Nurdin Mohammad)

5. Bersama, Pengelola Rumah Adat Bantayo Pobo'ide Pensiunan Pegawai Negeri Sipil (Hj. Rukmin Otaya) 